\title{
ALPHADIONE (ALTHESIN®): A NEW INDUCTION AGENT
}

\author{
M.G. Soliman ANd G.F. BRINDLE*
}

THE SEARCH for the ideal induction agent still continues. Since Selye $\mathrm{e}^{1,2}$ in 1942 demonstrated the anaesthetic properties of steroids, several steroid derivatives have been tried as anaesthetic agents. Hydroxydione was introduced into clinical anaesthesia in 1955. Its slow onset of action and tendency to produce phlebitis led to its early withdrawal.

Alphadione, better known as Althesin ${ }^{\circledR}$, is a new steroid intravenous induction agent. It consists of a mixture of alphaxalone and its 21 acetoxy ester, in a ratio of 3 to 1, dissolved in cremophor EL (Figure 1).<smiles>CC(=O)C1CCC2(C)C3CCC4=CC(=O)CCC4C3CCC12C</smiles>

PROGESTERONE<smiles>CC(=O)COC(C)=O</smiles>

HYDROXYDIONE

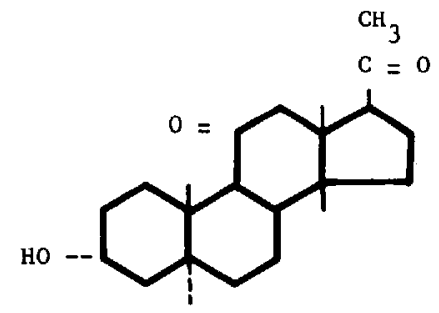

ALPHAXALONE

Figune 1.

•Centre Hospitalier Universitaire, Université de Sherbrooke, Sherbrooke, Québec. 
'TABI.E I

PATIENT IDENTIFICATION

\begin{tabular}{|c|c|c|c|c|c|c|}
\hline \multirow[b]{2}{*}{ No. } & \multirow[b]{2}{*}{ Age } & \multicolumn{2}{|c|}{ Sex } & \multicolumn{2}{|c|}{ Risk (A.S.A.) } & \multirow{2}{*}{$\begin{array}{l}\text { Mean surgical time } \\
\text { in minutes }\end{array}$} \\
\hline & & $\mathbf{M}$ & $\mathrm{F}$ & 1 & 2 & \\
\hline 57 & $9-64$ & 14 & 43 & 42 & 15 & 28.7 \\
\hline
\end{tabular}

TABI,E II

Analesthetic Techniqul:

\begin{tabular}{|c|c|c|c|c|c|c|}
\hline \multicolumn{2}{|c|}{ Premedication } & \multicolumn{2}{|c|}{ Intubation } & \multicolumn{3}{|c|}{ Maintenance } \\
\hline Yes & No & Yes & No & Enflurane & Halothane & Intravenous \\
\hline $2 i$ & 32 & 36 & 21 & 31 & 10 & 16 \\
\hline
\end{tabular}

Several advantages have been claimed in favour of Althesin as an induction agent over the commonly used barbiturates ${ }^{3-6}$ and the early steroids. Among the advantages cited are pleasant and rapid onset of sleep, short duration and minimal after effects, suppression of laryngeal reflexes, and relaxation of the muscles of the airway, lack of irritation of the blood vessels and a high therapeutic index. In this communication we report our experiences with Althesin ${ }^{(3)}$ as an induction agent.

\section{Method}

Fifty-seven patients ranging in age from 9 to 64 years were the subjects of study. The majority were A.S.A. class 1 , undergoing elective operations of short duration (Table I).

A summary of the anaesthetic technique used is shown in Table II. Twenty-five patients received diazepam $10 \mathrm{mg}$ intramuscularly one hour before operation.

After establishing an intravenous infusion of dextrose 5 per cent in Ringer's lactate, the vital signs were recorded and anaesthesia was induced with Althesin ${ }^{\circledR}$ in a dose of $0.07 \mathrm{ml} / \mathrm{kg}$ given over a period of 10 seconds $(9 \mathrm{mg}$ alphaxolone and 3 $\mathrm{mg}$ alphadolone $/ \mathrm{ml}$ ). The interval between the end of injection and onset of sleep was recorded and vital signs were observed in all patients every minute for five minutes and then every two minutes for another ten minutes.

In 36 patients succinylcholine $(1 \mathrm{mg} / \mathrm{kg}$ ) was given two minutes after induction to facilitate tracheal intubation. Anaesthesia was maintained with nitrous oxide, oxygen and enflurane (1-3 per cent) in 31 patients, with halothane, (0.5-2 per cent) nitrous oxide, oxygen in ten patients and with Althesin ${ }^{\circledR}$, Innovar ${ }^{\circledR}$ or narcotics intravenously in 16 patients.

At the end of operation the patients were observed for return of orientation. The time elapsed between the end of operation and orientation was registered. Patients were judged well oriented when they could state where they were, what type of operation they had undergone and could tell the approximate time of day.

Vital signs were observed for a period of two hours during recovery and the patients were questioned about dreams or recall during the operation. The site of the Althesin injection was also examined for signs of irritation. 
TABLE III

EFFECT OF $0.07 \mathrm{MG} / \mathrm{KG}$

\begin{tabular}{ccccc}
\hline \hline Total No. & $\begin{array}{c}\text { Dose } \\
\text { No. }\end{array}$ & $\begin{array}{c}\text { Adequate } \\
\%\end{array}$ & $\begin{array}{c}\text { Dose } \\
\text { No. }\end{array}$ & $\begin{array}{c}\text { Adequate } \\
\%\end{array}$ \\
\hline 57 & 53 & 93 & 4 & 7 \\
\hline
\end{tabular}

TABLE IV

The Mean Time in Seconds Between Injection and Sleep

\begin{tabular}{rcc}
\hline All patients & With premedication & Without premedication \\
\hline S.D. $\pm \begin{array}{r}45.5 \\
2.8\end{array}$ & S.D. $\pm \begin{array}{r}41.3 \\
3.4\end{array}$ & S.D. \pm 46.5 \\
\hline
\end{tabular}

'TABLE V'

Mean Time in Minutes Between The End of Operation and RETURN OF Orientation

\begin{tabular}{ccc}
\hline \hline All patients & With premedication & Without premedication \\
\hline 9.3 & S.D. $\pm 15.3^{*}$ & $4.25^{*}$ \\
S.D. \pm 1.6 & S.D. \pm 0.6 \\
\hline
\end{tabular}

*Statistically significant.

\section{Results}

Table III shows the effect of Althesin ${ }^{\circledR}$ in a dose of $0.07 \mathrm{ml} / \mathrm{kg}$ for the induction of sleep. In 53 patients this dose was adequate, while in four patients a supplementary dose of $0.01-0.02 \mathrm{ml} / \mathrm{kg}$ was required.

The interval between the end of the Althesin injection and the onset of sleep is shown in Table IV. The mean time was $45.5 \pm 2.8$ seconds, being shorter in premedicated than in non-premedicated patients. The difference was not statistically significant.

Table V shows the mean time in minutes $(9.3 \pm 1.6)$ between the end of operation and recovery of orientation. There was a statistically significant difference between premedicated and non-premedicated patients. The use of Althesin for the maintenance of anaesthesia had no significant effect on the length of time to return of orientation.

Table VI shows the changes in some cardio-vascular parameters after Althesin induction. About 60 per cent of our patients developed sinus tachycardia of 20 to 50 per cent of the pre-induction level. No arrhythmias were observed. Eighteen patients showed a decrease in blood pressure of 10 to 15 per cent of the preinduction level. These changes returned to control levels within a few minutes after induction. Some degree of hypertension of brief duration was observed after laryngoscopy and intubation in those patients in whom a tracheal tube was used.

The incidence of respiratory depression and apnoea in this group of patients is shown on Table VII. Apnoea of 30 to 60 seconds' duration occurred in 65 per cent of our patients. Apnoea was preceded by a few rapid deep breaths.

The incidence of involuntary movement during induction is shown in Table VIII. 
TABLE VI

Cardiovasculak Changes

\begin{tabular}{|c|c|c|c|c|c|}
\hline \multicolumn{3}{|c|}{ Tachycardia } & \multicolumn{3}{|c|}{ Hypotension } \\
\hline No. & $\begin{array}{c}\text { Percentage } \\
\text { of } \\
\text { patients }\end{array}$ & $\begin{array}{l}\text { Percentage } \\
\text { increase }\end{array}$ & No. & $\begin{array}{c}\text { Percentage } \\
\text { of } \\
\text { Patients }\end{array}$ & $\begin{array}{c}\text { Percentage } \\
\text { decrease }\end{array}$ \\
\hline 34 & 59.6 & $20-50$ & 18 & $31 . \overline{5}$ & $10-1 i$ \\
\hline
\end{tabular}

TABLE VII

Respikatory Changes

\begin{tabular}{|c|c|c|}
\hline \multicolumn{2}{|c|}{ Respiratory depression } & \multirow[b]{2}{*}{ Duration of apnoeal } \\
\hline No. & Percentige of patients & \\
\hline 37 & 65 & $30-60$ seconds \\
\hline
\end{tabular}

TABLE VIII

INVOLUNTARY MOVEMENT

\begin{tabular}{cccccccc}
\hline \multicolumn{2}{c}{ Eye Lids } & & \multicolumn{2}{c}{ Facial muscles } & & \multicolumn{2}{c}{ More than facial muscles } \\
\cline { 5 - 7 } No. & $\%$ & & No. & $\%$ & & No. & $\%$ \\
\hline $3 \pi$ & 61.5 & & 8 & 14 & & 8 & 14 \\
\hline
\end{tabular}

TABILE IX

OTher EfFects

\begin{tabular}{|c|c|c|c|c|c|c|c|}
\hline \multicolumn{2}{|c|}{ Hiccup } & \multicolumn{2}{|c|}{ Cough } & \multicolumn{2}{|c|}{$\begin{array}{l}\text { Increased salivation } \\
\text { and secretion }\end{array}$} & \multicolumn{2}{|c|}{ Skin rasli } \\
\hline No. & $\%$ & No. & $\%$ & No. & $\%$ & No. & $\%$ \\
\hline 2 & $3 . \overline{3}$ & 1 & 1.75 & $s$ & 15 & 3 & 5.2 \\
\hline
\end{tabular}

Twitching of the eyelids occurred in 61.5 per cent of the patients; in eight patients these twitches progressed to involve other muscles of the face and upper limbs. All were mild and of only a few seconds' duration.

Other observed effects of Althesin are listed in Table IX. Hiccup occurred in two patients and cough in one. A mild skin rash was observed in three patients; it was mostly in the upper half of the body and disappeared within a few minutes. One patient complained of nausea.

During the recovery period all cardio-vascular and respiratory parameters were within the pre-induction limits. No dreams or recall during operation were reported. There were no complaints of burning or pain during injection and no signs of vascular irritation were observed. 


\section{Discussion}

The results obtained in these patients suggest that Althesin ${ }^{\circledR}$ is a satisfactory induction agent with some pharmacological effects similar to but less intense than those of the commonly used barbiturates.

The rapid recovery of orientation with minimal after effects even when repeated doses of Althesin have been used constitute a major advantage over barbiturates as an induction agent for surgical outpatients, ${ }^{7-10}$ since its use may lead to a shorter, more pleasant recovery period with a rapid return to normal activity.

The short duration of the hypnotic effect of Althesin is due mainly to its rapid detoxication. Child et al., ${ }^{11}$ studying the metabolism and excretion of Althesin in rats, found that it had a half-life of seven minutes with the metabolic products detectable in the urine over a period of five days.

Short-lived respiratory depression preceded by respiratory stimulation was observed in most patients. Similar observations were described by du Cailar, ${ }^{12}$ while Tomlin found that Althesin produced minimal effects on respiratory mechanics and airway dynamics. ${ }^{13}$

We have not observed laryngeal or bronchial spasm during or after induction, suggesting that Althesin may be a useful agent in asthmatic patients. Further studies are needed, however, since the results of an enquiry conducted by staff of the University of Liverpool on the use of Althesin in Great Britain ${ }^{14}$ showed that the majority of anaesthetists felt that Althesin is contra-indicated in asthmatic patients.

One of the disadvantages of Althesin is its relative insolubility in water. The cremophor EL used as a solvent may result in sensitivity and several cases have been reported, Dundee describing an incidence of less than one in 20,000 cases..$^{15}$ Five per cent of our patients had an erythematous rash over the chest which disappeared within a few minutes and seemed to be of no consequence.

An increase in the heart rate has been observed in about 60 per cent of our patients. Similar results had been described in other studies. ${ }^{12,10}$ The absence of an apparent cause, such as abnormality of the blood gases, ${ }^{12}$ suggest that the increase in the heart rate may be due to a direct action of the drug.

The positive chronotropic effect with minimal changes in the blood pressure indicates that Althesin may be preferable to barbiturates in patients with cardiovascular disease. ${ }^{17,18}$ However, in a study of induction agents in hypertensive patients, Prys-Roberts ${ }^{19}$ found no advantage of Althesin over thiopentone. The positive chronotropic effect may contra-indicate its use in patients with coronary artery disease. ${ }^{20}$

\section{SUMMARY}

The use of Althesin for induction of anaesthesia in 57 patients showed that it is a satisfactory induction agent.

However, with the exception of rapid recovery with minimal after-effects, it has no major advantages over the commonly used barbiturates.

\section{RÉSUMÉ}

L'althesin s'est montré un agent d'induction satisfaisant chez 57 patients. Ce- 
pendant, il ne présente pas d'avantage majeur sur les barbituriques d'emploi courant, si ce n'est un éveil rapide et une incidence minime d'effets secondaires.

\section{REFERENCES}

1. Selye, H. The anaesthetic effects of steroid hormones. Proc. Soc. Exp. Biol. Med. 46: 116121 (1941).

2. SELXE, $\mathrm{H}$. Correlations between the chemical structure and the pharmacological actions of steroids. Endocrinology 30: 437-543 (1942).

3. Clark, R.S.J., Carson, J.W., \& Dundee, J.W. Some aspects of the clinical pharmacology of althesin. Post. Grad. Med. J., June Suppl. pp. 62-65 (1972).

4. Campbeli, D., Forrester, A.C., \& Miller, D.C. A preliminary clinical study of CT-134l - A steroid anaesthetic agent. Br. Jour. Anaes. 43: 14 (1971).

5. Swerdiow, M. Studies with althesin, a new steroid anaesthetic agent. Post. Grad. Med. J., June suppl. pp. 108-110 (1972).

6. GYERMEK, L. \& SoYKa, L.F. Steroid anaesthetics. Anesthesiology 42: pp. 331-344 (1975).

7. Elanor, I., Foley, Walton B., Savege, T.M., \& Strunin, L. Comparison of recovery times between althesin and methohexitone following anaesthesia for electro-convulsive therapy. Post. Grad. Med. J., June suppl. pp. 112-115 (1972).

8. Cooper, J. Althesin in outpatient psychiatric practice. Post. Grad. Med. J., June suppl. pp. 115-116 (1972).

9. HaNNington-KIFF, J.G. Comparative recovery rates following induction of anaesthesia with althesin and methohexitone in outpatients. Post. Grad. Med. J., June suppl. pp. 116119 (1972).

10. Carson, I.W., Graham, J., \& Dundee, J.W. Clinical studies of induction agents - XLIII: Recovery from althesin - A comparative study with thiopentone and methohexitone. Br. Jour. Anaes. 47: 358 (1972).

11. Chimd, K.J., Gibson, W., Harnby, G., \& Hart, J.W. Metabolism and excretion of althesin CT-1341 in the rat. Post. Grad. Med. J., June suppl., pp. 37-42 (1972).

12. Du Cailar, J. The effects in man of infusions of althesin with particular regard to the cardiovascular system. Post. Grad. Med. J., June suppl. pp. 85-89 (1972).

13. Tomuin, P.J. The respiratory effects of althesin. Post. Grad. Med. J., June suppl. pp. 85-89 (1972).

14. Special issue on althesin. Annales de l'Anesthésiologie Française, Suppl. 1973.

15. DundeE, J.W. \& WYANT, G.M. Intravenous anaesthesia (1st edition). Churchill Livingston, Edinburgh and London (1974).

16. Savege, T.M., Ekanor, I., Foley, Ross L., \& Maxwell, M.P. A comparison of the carcliorespiratory effects during induction of anaesthesia of althesin with thiopentone and methohexitone. Post. Grad. Med. J., June suppl. pp, 66-72 (1972).

17. Millek, D.C., Elizabeth, M., Bradford, W., \& Campbedl, D. Hemodynamic effects of althesin in poor risk patients. Post. Grad. Med. J., June suppl. pp. 133-137 (1972).

18. BrandLY, J.N. \& TAYLOR, P.A. An assessment of althesin for the induction of anaesthesia in cardiac surgical patients, a comparison with thiopentone. Br. Jour. Anaes. 46: 687 (1974).

19. Prys-Roberts, C., Foex, P., \& Biro, G.P. Cardiovascular responses of hypertensive patients to induction of anaesthesia with althesin. Post. Grad. Med. J., June suppl. pp. 80-84 (1972).

20. Wynands, J.E., Sheridan, C.A., Batra, M.S., Palmar, W.H., \& Shanks, J. Coronary artery disease. Anesthesiology 33: $260(1970)$. 